University of Nebraska - Lincoln

DigitalCommons@University of Nebraska - Lincoln

Space, Cyber, and Telecommunications Law

Program Faculty Publications

1996

\title{
The Role of Law with Respect to Future Space Activities
}

Frans von der Dunk

University of Nebraska - Lincoln, fvonderdunk2@unl.edu

Follow this and additional works at: https://digitalcommons.unl.edu/spacelaw

Part of the Air and Space Law Commons

von der Dunk, Frans, "The Role of Law with Respect to Future Space Activities" (1996). Space, Cyber, and Telecommunications Law Program Faculty Publications. 53.

https://digitalcommons.unl.edu/spacelaw/53

This Article is brought to you for free and open access by the Law, College of at DigitalCommons@University of Nebraska - Lincoln. It has been accepted for inclusion in Space, Cyber, and Telecommunications Law Program Faculty Publications by an authorized administrator of DigitalCommons@University of Nebraska - Lincoln. 


\title{
The Role of Law with Respect to
}

\section{Future Space Activities}

\author{
Frans G. von der Dunk
}

Frans von der Dunk ( fvonderdunk2@unl.edu ), currently of the University of Nebraska-Lincoln, is former Co-Director of the International Institute of Air and Space Law at Leiden University, Leiden, The Netherlands.

\begin{abstract}
With the enormous increase of space activities the question arises as to what extent law does or should play a role in preserving the interests of mankind at large in the use of outer space. Furthermore, it should be asked whether the present legal framework requires only slight modification, or a complete overhaul, in order to cope with these developments. It is concluded that the law as it stands today provides a largely satisfactory regime for the time being, whereas establishment of a new regime from stratch would create far more problems than it would solve.
\end{abstract}

It is slightly over 25 years ago that Neil Armstrong made his famous comment upon what represented the culmination of decades of dedicated space activities. Since then, however, one cannot escape the feeling that the sense of overall direction in space activities has largely been lost. So a fundamental question has now become: how space, after the moon?

So far, it is mainly visionaries who have focused on grand schemes and have taken center stage in presenting us with ideas in this respect. The growing relevance of their visions however is testified by the increasing shortening of their timetables. The design of Declan O'Donnell for instance ${ }^{1}$ uses a time frame of no more than sixteen years, calling for ratification for his Draft treaty providing the ultimate legal status of outer space no later than 2010.

\section{The legal dimension of outer space}

This brings us to the role of law on these visionary and futuristic issues. For law has indeed a fundamental task here, when it comes to moving human society and civilization into outer space.

First of all, law so far is - and indeed should be, in outer space as much as elsewhere-aimed at human actions, It does not make sense to oblige the mountains to move or prohibit the seas to surge. Law can choose for this purpose between aiming at man directly or indirectly, in the latter case by addressing itself to a specific activity or set of activities.

Either way, law with respect to outer space applies to human activities in a peculiar fashion, since most space activities have so far been 'unmanned,' that is: actually remotecontrolled. Here, space law applies to humans on earth undertaking activities occurring in outer space. ${ }^{2}$ The same space law however also appliesand indeed should apply for the purposes of consistency and logic-to manned space activities, where both man and his activities find themselves in outer space, and which should concern us most.

Law furthermore has a basically dual purpose. Many laws are established in order to create some kind of justice, or at least work towards it; the creation of many others has been motivated by an urge to create some 'rules for the road;' still many more have elements of both. ${ }^{3}$

In respect of the law applying to outer space, we find the same dichotomy. Law often operates here as a regulatory instrument for society; as a

1 See O’Donnell, D., Metaspace: A Design for Governance in Outer Space. Space Governance (1994) 1: 8-17.

2 One could take note in this respect, for example, of the title and structure of the Outer Space Treaty.

3 Some scholars see a trend consisting of a shift from the one to the other; so e.g. H.A. Wassenbergh, Principles of Outer Space Law in Hindsight (1991): 7-11; and diametrically opposed M.M.TA Brus, Concluding Observations, 6 Leiden Journal of International Law (1993): 386-387.

4 See Articles I, II, Outer Space Treaty.

5 Cf. Article VIII, Outer Space Treaty; also Article 11(2), Registration Convention. 
mechanism influencing and regulating inter-human relationships and as a man-made instrument, it should probably try to stick to such modest aims.

At the same time, driving right or driving left are equally viable rules for regulating traffic. Since 'left' and right' lose their meaning in the endless realm of outer space, the most important thing here is to choose, rather than which choice is to be made. And very often, it is some sense of 'what is right' prevailing within the given society which ultimately determines that choice.

Finally, law in relation to such a realm-where so far only some hundreds of human beings have intruded and even unmanned activities retain a predominantly pioneering, unpredictable and ad hoc character-cannot be built exclusively on the premise of a simple regulatory role. Law in relation to outer space therefore has to be built, for an important part, on the premise of a justiceenhancing role. If the rather exclusive experience of travel and shortterm presence in space undertaken so far is to evolve into permanent habitats meta-legal concepts become involved where choices between 'left' and 'right' can not be made on utilityjudgements alone-but nevertheless some sort of predictability and clarity has to be provided for future endeavors.

On this point, another dichotomy arises. Law follows day-to-day developments rather more than it precedes them. The major task here, on the one hand, lies in preventing law from running too far behind, for then law would risk becoming a nuisance, and be an obstacle to progress and development. On the other hand, it also lies in preventing law from running too far ahead, for then law would risk becoming irrelevant. since nobody can presage the future and the legal rules needed in all their aspects.

That, therefore, is the ultimate challenge for law to master in outer space. Whether choosing between 'right' or 'left' as a regulatory instrument, or between 'right' and 'wrong' as a tool of justice; law should not lay down inflexible blueprints for the future. At the same time, as long as the pioneer character of space activities remains paramount and no certainty can be provided with respect to what actions might be necessary or what consequences such actions would entail, law should not add to the insecurity either.

Law should adhere to the most fundamental principles of international (space) law which have so far weathered all storms. Precisely because of the flexibility needed, moreover, when it comes to envisaging what particular activities might take place in the future and the substantiative rules needed as a consequence, these principles relate to the structure of applying law, and not so much to its actual contents.

These fundamental principles boil down to the fact that all space activities are undertaken in the sovereignty-free, truly internationalized res communis which is outer space, including its celestial bodies. ${ }^{4}$ Sovereignty as a monolithic phenomenon presents the best example of an international legal principle structuring the application of law, and the exclusion of sovereignty as such, even under today's law of outer space, does not exclude the exercise of certain sovereign rights by the states of this earth in outer space. Here, the largest possible freedom-being active in spaceis reconciled with the need to exercise some measure of legal control one way or another over what is brought about in outer space by human causation.

First, there is the jurisdiction of states over persons with their nationality, as already in existence under general public international law. Space law does not touch upon the continuing application of this sovereign right. Secondly, there is the jurisdiction of states over their space objects and personnel on board as specifically provided for by space law. ${ }^{5}$ This really is quasi-territorial jurisdiction, akin to the common territorial jurisdiction of states down on earth, only far less comprehensive. By providing space objects with a kind of nationality, space law transforms them into such pieces of quasi-territory of the particular state in question, inviting the concurrent exercise of jurisdiction. 
So far, human presence in outer space has been restricted to a relatively short presence on board space objects launched from the earth, travelling through outer space and soon returning to earth. The jurisdiction based on nationality in combination with the jurisdiction based on the quasi-nationality of the space object makes for a rather effective structure of legal control over these manned space activities.

The phenomenon of the so-called EVA's-extra-vehicular activities-in which the persons concerned left the space object in question and were themselves actually floating in outer space, did not threaten the effectiveness of this structure. The human actors could still clearly be linked, not only in a theoretical way (they are never outside of the space object for more than a few hours), but also in a practical way through their umbilical cords, with the space object of departure and destination-and hence with the state of jurisdiction exercising legal control over their actions.

However, if the human presence in space extends beyond such an EVAframework, resulting in permanent human habitats in outer space, it may be questioned whether the present international space law will still suffice, or whether the present structure, focused on the sovereignty of national states, should be radically overhauled and a legal framework rebuilt from scratch, able from the beginning to take account of all the special characteristics of this truly giant leap for mankind.

\section{The future role of law in outer space}

If law is to fulfill its role of providing clarity and predictability, and probably some measure of justice too, even vis-à-vis a fundamental annexation of outer space in a fashion not obstructed by national rivalries, the freedom of undertaking outer space activities as presently guaranteed is to remain in balance with some measure of legal control. Space should not become a free-for-all, and for example the obligatory peaceful purpose of space activities should con- tinue to be respected. Clearly, not providing any system of legal control could make outer space into a chaotic and basically lawless free-for-all. But even a different approach from the one taken in this paper to the establishment of legal control would run into large difficulties. Any newly invented structure would have quite a backlog to compensate for in these respects.

Such a structure would not easily provide a comprehensive apparatus for effective legal protection of, and legal control over, any well-defined category of humans. Until human beings start living major parts of their lives in outer space, their nationalitybonds with their states of origin will remain strong enough to justify continued legal control over them by those states. Doing away with their nationality would effectively make them stateless unless another entity steps into the void to provide them with a new 'nationality' and the substantial and practical benefits which always form the mirror-side of nationality.

Neither would a newly invented structure instantly have the power to exercise even quasi-territorial jurisdiction without an effective machinery with comprehensive legislative, executive and judicial instruments to back it up. Thus, the quasi-territorial jurisdictions of states over space objects should be preserved. Actually, it should be extended to parts of celestial bodies as soon as they become permanently occupied by humans, in order to equate celestial cities on celestial bodies with celestial cities in free-flying earth-made structures.

The stress here is on both 'quasi' and 'territoriality.' On the one hand, the territorial principle is the best way to exercise comprehensively legal control over human actions in a certain part of outer space. On the other hand, the basic internationally established rules applicable to space-no sovereignty as such, freedom of exploration and use, exploration and use only for peaceful purposes, and a few others-should continue to form the boundaries of any individual state's exercise of sovereign rights and jurisdiction in outer space. 
This present quasi-territorial approach first relates well to the size and complexity of any future habitat, of which space stations are merely the infant examples. Extending territory for the purpose of enlarging the geographical reach of an already existing system, even if due account is taken of the international limitations on sovereign rights of national states, is a far easier and more evolutionary approach than trying in advance to include all the aspects of life and human activities in such a complex structure by creating a whole separate system. It preserves clarity and predictability, and hence serves to maintain the balance.

The quasi-territorial approach would, secondly, make more sense in view of the semi-territorial nature of permanent space colonies. An important consequence of the habitability of space stations is the factual status of such space stations: they are no longer mere transport vehicles-so far with the exception of the Russian Mir which constitutes the only manned space station-but much more akin to a piece of territory floating in outer space. This argument is even stronger in respect of permanent habitats, whether freefloating or based upon a celestial body. As long as the metaphorical umbilical cords with earth still remain of essential importance, an imposition of a new structure for the application of law would be unpractical, and would only complicate clarity and predictability.

Thirdly, human colonization of outer space would necessitate space habitats becoming normal, earth-like environments. Consequently they should provide the possibility for all kinds of human activities, activities which may have little or no relevance from a space law point of view, and yet will have to be dealt with legally. The sale in outer space of a photo camera to someone else has not got much to do with space law, yet in principle it has to be dealt with legally. Such a transaction is fundamentally no different from an earthbound transaction of the same kind, however, so why should a new system reinvent the wheel here, when it would only create confusion in its constant comparison with equal but earthbound activities?

Fourthly, the tendency towards the internationalization of such large space structures as space stations-let alone of whole cities - in outer space will bring jurisdictional questions to the forefront anyway, as in principle different jurisdictions will continue to be at stake ${ }^{6}$. Why not deal with them in a comprehensive fashion then, with the advantage of building upon centuries of legal experience with these legal doctrines as they operated on earth?

\section{How law?}

From the structural perspective therefore, the present tools of law still show the way to go forward. Consequently, the principles of the freedom of activities in outer space (within bounds) and of the continued exercise of national jurisdictions (also within bounds), already applicable under outer space law in a nicely working balance, should not be done away with, at least before space activities have become routine, for it reflects a time-proven method for organizing legal control over human activities.

History seems to support this choice of an evolutionary approach ultimately leading to a fundamental adaptation of the system for the colonization of outer space by humans. In the case of the U.S.A. for instance, after many decades of exploration in a totally new and rather hostile environment under the legal umbrella of the sovereignty of Great Britain, the old legal order was reread, and the U.S.A. became a state of its own, based on and justified by the distance to the mother country. By doing so, it became a new entity in the same old system, rather than a new system on its own.

This shows that, while law may not present a perfect tool for perfect happiness and justice all around, it is structurally speaking an important instrument in furthering the cause of humanity, even out there in space, by balancing clarity and predictability with flexibility and progress. Without therefore belittling in any sense those visionaries who leapfrog the years and present the final picture, in a very fundamental sense the question: How space? should begin to be answered by: How law?! 